\title{
PENGARUH PENERAPAN MODEL PEMBELAJARAN PENEMUAN TERBIMBING TERHADAP PEMAHAMAN KONSEP MATEMATIKA SISWA KELAS XI MIPA NON UNGGULAN SMA NEGERI 1 BANGLI
}

\author{
N.K.Juliawati, I.G.P.Suharta, I.P.P.Suryawan \\ Jurusan Pendidikan Matematika Universitas Pendidikan Ganesha \\ Singaraja, Indonesia \\ email: julyawaty80@gmail.com, igpsuharta@yahoo.com, pasek.suryawan@yahoo.co.id
}

\begin{abstract}
Abstrak
Penelitian ini bertujuan untuk mengetahui apakah pemahaman konsep matematika siswa yang dibelajarkan dengan model penemuan terbimbing lebih baik daripada pemahaman konsep matematika yang dibelajarkan dengan pembelajaran konvensional. Populasi dalam penelitian ini adalah siswa kelas XI MIPA Non Unggulan SMA Negeri 1 Bangli pada semester II tahun ajaran 2017/2018. Kelas XI MIPA SMA Negeri 1 Bangli tersebar ke dalam 7 kelas dan terdapat satu kelas unggulan yaitu kelas XI MIPA 1 sehingga populasi dalam penelitian ini adalah kelas XI MIPA 2, XI MIPA 3, XI MIPA 4, XI MIPA 5, XI MIPA 6, dan XI MIPA 7. Sampel penelitian ditentukan dengan teknik cluster random sampling. Teknik pengambilan sampel dilakukan dengan pengundian terhadap 6 kelas yang merupakan populasi. Setelah dilakukan pengundian, terpilih 2 kelas yakni kelas XI MIPA 2 dan kelas XI MIPA 3 sebagai sampel penelitian. Berikutnya, dilakukan uji kesetaraan dengan uji-t terhadap kedua kelas tersebut. Hasil uji kesetaraan menunjukkan bahwa kedua kelas dinyatakan setara. Kemudian, dilakukan pengundian kembali terhadap kedua kelas sehingga diperoleh kelas XI MIPA 2 sebagai kelas eksperimen dan kelas XI MIPA 3 sebagai kelas kontrol. Penelitian ini dikategorikan penelitian eksperimen semu dengan desain penelitian post-test only control group design. Data tentang kemampuan pemahaman konsep matematika siswa dikumpulkan melalui tes pemahaman konsep matematika siswa. Selanjutnya skor tes pemahaman konsep matematika dianalisis dengan menggunakan uji-t satu ekor (ekor kanan) pada taraf signifikansi $5 \%$. Hasil analisis menunjukkan bahwa thitung $=1,87$ sedangkan dengan gtaraf signifikansi $5 \%$ diperoleh tabel $=1,671$. Nilai statistik ini memiliki makna bahwa pemahaman konsep matematika siswa yang dibelajarkan dengan model penemuan terbimbing lebih baik dibandingkan dengan pemahaman konsep matematika siswa yang dibelajarkan dengan pembelajaran konvensional.
\end{abstract}

Kata Kunci: model pembelajaran penemuan terbimbing, pemahaman konsep matematika siswa, Lembar Kerja Siswa Penemuan Terbimbing.

\begin{abstract}
Abstrack
This study was conducted with the aim to determine whether the students mathematical concept comprehension whom were taught by the guided discovery learning better with the students mathematical concept comprehension taught by conventional learning. The population of this study was the regular XI MIPA classes of SMA Negeri 1 Bangli on the second semester of 2017/2018 academic year. The XI MIPA class of SMA Negeri 1 Bangli were divided into 7 classes, among which one was a superior classes namely XI MIPA 1 therefore the population of this study were XI MIPA 2, XI MIPA 3, XI MIPA 4, XI MIPA 5, XI MIPA 6, and XI MIPA 7. The sample of this study was determined by cluster random sampling technique. The sampling technique was conducted by lottery the 6 classes of the population. After the draw, two classes were chosen, namely XI MIPA 2 class and XI MIPA 3 class as the samples of the research. Next, an equality test with the t-test was performed on both classes. The result of equality test showed that both classes are equal. Then, the draw was made again to the two classes and the result of the draw determine that the XI MIPA 2 class was obtained as the experimental class and the XI MIPA 3 class as the control class. This research was categorized as quasi experiment research with posttest only controls group design. The data of the students mathematical concept comprehension was collected using the students mathematical concept comprehension test. And then, the result of the test were analyzed by using t-test one tail (right tail) at $5 \%$ significance level. The result of analysis showed that tcount $=1,87$ whereas with $5 \%$ significance level obtained table $=1,671$. This statistic value meant that comprehension of mathematics concept of student whome where taught
\end{abstract}


by guided discovery learning was better than understanding of mathematics concept of student who where is taught by conventional learning.

Keywords: guided discovery learning model, students mathematical concept comprehension, guided discovery student worksheet.

\section{PENDAHULUAN}

Pada peraturan menteri pendidikan nasional nomor 22 tahun 2006 tentang Standar Isi untuk satuan pendidikan dasar dan menengah terlihat bahwa pemahaman konsep merupakan salah satu tujuan penting dalam pembelajaran matematika. Dengan memahami konsep matematis siswa akan lebih mudah untuk memecahkan masalah matematika yang diberikan guru.

Pemahaman konsep adalah salah satu aspek yang harus dimiliki siswa. Menurut Arends (2007: 322), "konsep adalah dasar untuk bernalar dan berkomunikasi secara baik dan benar karena mereka mempunyai pemahaman konsep yang mereka komunikasikan". Berdasarkan pendapat tersebut pula, bila siswa tidak memahami konsep dalam belajar, maka siswa akan kesulitan ketika dihadapkan pada permasalahan yang menuntut pemahaman siswa. Menurut NCTM (2000), terdapat tiga indikator pemahaman konsep. Ketiga indikator tersebut, yakni: 1) menyatakan konsep dengan kata-kata sendiri, 2) memberikan contoh atau bukan contoh dari konsep, serta 3) menggunakan konsep dengan benar dalam berbagai situasi. Sehingga pemahaman konsep yang baik menjadi hal yang penting pada pembelajaran.

Pada kenyataannya sebagian besar siswa Indonesia mengalami kesulitan dalam memahami konsep matematika. Hal ini tercermin dari hasil laporan Trends in International Mathematics and Science Study (TIMSS). Mullis dkk (2015) dalam tulisannya terkait laporan TIMSS menyatakan bahwa prestasi siswa Indonesia dalam bidang matematika mendapat peringkat 46 dari 51 negara dengan skor sebesar 397.

Rendahnya pemahaman konsep matematis siswa dipengaruhi oleh banyak faktor, salah satunya adalah model pembelajaran yang diterapkan guru di kelas. Beberapa sekolah yang sudah menerapkan kurikulum 2013 sudah berusaha untuk menerapkan model pembelajaran yang disarankan dalam kurikulum 2013. Namun, pada pelaksanaannya di lapangan belum bisa maksimal sebagaimana yang dicantumkan dalam dokumen RPP.

Sebagian besar guru yang mengajar di sekolah yang memakai kurikulum 2013, sudah berusaha menerapkan model pembelajaran yang disarankan dalam kurikulum 2013. Adanya kesulitan guru dalam penerapannya membuat guru tidak maksimal dalam menerapkan model ini di dalam kelas. Siswa lebih banyak diberikan latihan soal-soal terkait materi yang diajarkan setiap pertemuannya. Dengan kata lain, siswa tidak dilibatkan dalam penemuan konsep matematika. Hal inilah yang menyebabkan pemahaman konsep matematika siswa rendah.

Menyikapi permasalahan yang terjadi di lapangan sebagaimana yang dipaparkan di atas, model pembelajaran yang sesuai digunakan untuk mengatasi permasalahan tersebut adalah model pembelajaran penemuan terbimbing. Model pembelajaran penemuan terbimbing adalah suatu model yang menghadapkan siswa pada situasi dimana mereka bebas menyelidiki dan menarik kesimpulan sedangkan guru mengarahkan siswa untuk membuat terkaan, intuisi dan mencoba-coba.

Model pembelajaran penemuan terbimbing ini sangat efektif dalam mengontruksi pemahaman konsep peserta didik. Hal ini dapat dilihat dari keterkaitan antara sintaks model pembelajaran penemuan terbimbing dengan indikator pemahaman konsep. Model pembelajaran penemuan terbimibing memiliki langkahlangkah pembelajaran yakni: fase stimulation (pemberian rangsangan), fase problem statement (mengarahkan siswa untuk mengajukan pertanyaan terkait materi yang disampaikan), fase data collection (mengumpulkan data), fase data processing (pengolahan data), fase verification (pemeriksaaan secara cermat terkait 
benar/tidaknya hipotesis, dan fase generalization (menarik sebuah kesimpulan secara umum terkait dengan hasil yang diperoleh pada tahap verifikasi).

Pada fase stimulation, guru akan mengarahkan peserta didik mengingat materi yang diberikan sebelumnya serta akan menyampaikan manfaat terkait materi yang akan diajarkan sehingga peserta didik termotivasi untuk mengikuti pembelajaran. Pada fase problem statement, guru akan mengarahkan peserta didik untuk menemukan permasalahan-permasalahan yang berkaitan dengan materi yang akan diajarkan. Fase problem statement ini menuntut peserta didik untuk dapat mengungkapkan konsep-konsep terkait materi sebelumnya dengan kata-kata sendiri sehingga mereka dapat menentukan permasalahan-permasalahan yang berkaitan dengan materi yang diajarkan untuk selanjutnya akan dipilih satu pertanyaan yang akan dijadikan sebagai hipotesis.

Pada fase data collection, guru akan mengarahkan peserta didik mengumpulkan informasi-informasi untuk hipotesis yang sudah dirumuskan. Pada fase ini, siswa dituntut untuk mampu mengungkapkan konsep dengan kata-kata sendiri, memberikan contoh dan bukan contoh dari suatu konsep sehingga informasi yang mereka peroleh memang bisa mereka gunakan untuk membuktikan hipotesis yang sudah dirumuskan. Setelah informasi yang diperlukan berhasil terkumpulkan maka siswa akan mengolah data atau informasiinformasi tersebut untuk membuktikan hipotesis. Pada tahap ini siswa dituntut untuk mampu mengaplikasikan atau menggunakan konsep dengan benar sehingga mereka dapat menemukan konsep baru berdasarkan konsep-konsep yang sudah mereka kuasai sebelumnya.

Tahapan berikutnya adalah fase verification, pada tahap ini siswa akan melakukan pemeriksaan secara cermat untuk menunjukkan benar/tidaknya hipotesis yang mereka rumuskan. Pada tahap ini, siswa dituntut untuk mampu menyampaikan konsep dengan kata-kata sendiri serta memberikan contoh dan bukan contoh dari konsep sehingga mereka bisa membuktikan benar/tidaknya hipotesis berdasarkan hasil data processing. Fase terakhir adalah fase generalization, pada fase ini siswa dituntut untuk mampu menyimpulkan atau menggeneralisasi konsep sehingga dapat berlaku untuk umum. Pada tahap ini siswa dituntut untuk mampu menyampaikan konsep baru yang mereka peroleh dengan kata-kata sendiri, memberikan contoh dan bukan contoh dari konsep tersebut, serta menggunakan konsep tersebut dengan benar dalam berbagai situasi.

Keefektifan penerapan model pembelajaran penemuan terbimbing dalam pembelajaran matematika di kelas telah dibuktikan melalui beberapa penelitian. Penelitian yang dilakukan oleh Agung Fernando (2016) menunjukkan bahwa terdapat perbedaan yang signifikan terhadap minat belajar serta kemampuan pemecahan masalah siswa pada pembelajaran matematika materi pecahan yang dibelajarkan dengan pembelajaran dengan menerapkan model pembelajaran Penemuan terbimbing dengan siswa yang dibelajarkan dengan penerapan model pembelajaran konvensional.

Penelitian lainnya dilakukan oleh Noneng Rosmini (2015) menunjukkan bahwa penerapan model pembelajaran penemuan terbimbing terbukti dapat meningkatkan kemampuan penalaran dan sikap matematika siswa. Penelitian berikutnya, dilakukan oleh Ficha Diah Putri (2017), penelitian ini menunjukkan bahwa kemampuan representasi matematis siswa yang mengikuti model penemuan terbimbing lebih baik daripada siswa yang mengikuti pembelajaran konvensional.

Pemecahan masalah ataupun kemampuan representasi matematis sesungguhnya didasari oleh pemahaman konsep. Oleh karena itu, harus ditunjukkan pula terkait dengan pengaruh model penemuan terbimbing terhadap pemahaman konsep matematika siswa. Berdasarkan alasanalasan tersebut, peneliti tertarik untuk mengambil penelitian yang berjudul "Pengaruh Penerapan Model Pembelajaran Penemuan Terbimbing terhadap Pemahaman Konsep Matematika Siswa Kelas XI MIPA Non Unggulan SMA Negeri 1 Bangli". 


\section{METODE}

Jenis penelitian ini adalah penelitian eksperimen, dalam kategori penelitian eksperimen semu (quasi experiment). Penelitian eksperimen semu dapat dilakukan untuk melihat pengaruh yang ditimbulkan dari perlakuan berbeda yang diberikan pada masing-masing kelompok, yang mana peneliti tidak mengontrol semua variabel dan kondisi eksperimen secara ketat (Sugiyono, 2012: 114). Desain penelitian yang digunakan adalah "Post Test Only Control Group Design".

Desain penelitian ini dapat dilihat pada tabel di bawah ini.

Tabel 1. Desain Penelitian

\begin{tabular}{|c|c|c|}
\hline Kelompok & Perlakuan & $\begin{array}{l}\text { Post- } \\
\text { Test }\end{array}$ \\
\hline E & $\mathrm{X}$ & $\mathrm{Y}_{1}$ \\
\hline C & - & $\mathrm{Y}_{2}$ \\
\hline
\end{tabular}

(Dimodifikasi dari : Dantes,2012)

Keterangan:

E : Kelompok eksperimen

C : Kelompok kontrol

$\mathrm{X} \quad$ : Perlakuan berupa penerapan model pembelajaran penemuan terbimbing.

$Y_{1} \quad$ : Hasil Post-test Kelompok Eksperimen

$\mathrm{Y}_{2} \quad$ : Hasil Post-test Kelompok Kontrol

Populasi dalam penelitian ini adalah seluruh kelas XI MIPA Non Unggulan SMA Negeri 1 Bangli yang terdiri dari 7 kelas dengan total 193 siswa. Teknik pengambilan sampel dalam penelitian ini menggunakan cluster random sampling dengan sistem pngundian. Karena terdapat 1 kelas unggulan yaitu kelas XI MIPA 1 maka populasi dalam penelitian ini adalah kelas XI MIPA Non Unggulan. Selanjutnya dilakukan pengundian terhadap kelas XI MIPA Non Unggulan, terpilihlah dua kelas yakni kelas XI MIPA 2 dan kelas XI MIPA 3. Kedua kelas yang terpilih selanjutnya diundi kembali sehingga diperoleh kelas XI MIPA 2 sebagai kelas eksperimen dan kelas XI MIPA 3 sebagai kelas kontrol. Kelas XI MIPA 2 sebagai kelas eksperimen diberikan perlakuan dengan penerapan model pembelajaran penemuan terbimbing. Sedangkan kelas XI MIPA 3 sebagai kelas kontrol diberikan pembelajaran konvensional yang dalam penelitian ini pembelajaran konvensional yang dimaksud adalah model problem based learning semu.

Penelitian ini melibatkan variabel bebas dan variabel terikat. Variabel bebas dalam penelitian ini adalah model pembelajaran penemuan terbimbing. Adapun variabel terikat dalam penelitian ini adalah pemahaman konsep matematika siswa.

"Instrumen penelitian adalah alat yang digunakan oleh peneliti untuk mengumpulkan data atau informasi yang relevan dengan permasalahan penelitian" (Rully dan Poppy, 2014: 112). Jenis instrumen yang digunakan dalam penelitian ini berupa tes. Data yang akan dikumpulkan pada penelitian ini adalah berupa pemahaman konsep matematika siswa, yang dikumpulkan melalui tes tertulis yang berupa tes uraian. Adapun indikator yang menjadi acuan dalam penyekoran hasil tes kemampuan pemahaman konsep matematika siswa dapat dilihat pada rubrik penskoran sebagai berikut:

Tabel 2. Rubrik Penskoran Pemahaman Konsep Matematika

\begin{tabular}{lll}
\hline Indikator & Skor & Kategori \\
\hline \begin{tabular}{l} 
1. Menyatakan $\begin{array}{l}\text { konsep dengan } \\
\text { kata-kata sendiri }\end{array}$ \\
\cline { 2 - 3 }
\end{tabular} & 2 & $\begin{array}{l}\text { Menyatakan ulang konsep yang telah } \\
\text { dipelajari dengan katakata sendiri } \\
\text { dengan benar. }\end{array}$ \\
\cline { 2 - 4 } & 0 & $\begin{array}{l}\text { Menyatakan ulang konsep yang telah } \\
\text { dipelajari dengan kata-kata sendiri } \\
\text { namun belum benar. }\end{array}$ \\
\hline 2. Memberikan & 2 & $\begin{array}{l}\text { Salah menyatakan ulang sebuah } \\
\text { konsep. }\end{array}$ \\
\hline
\end{tabular}




\begin{tabular}{|c|c|c|}
\hline Indikator & Skor & Kategori \\
\hline \multirow{3}{*}{$\begin{array}{l}\text { Contoh dan bukan } \\
\text { contoh } \\
\text { konsep. }\end{array}$} & & $\begin{array}{l}\text { atau bukan contoh dari suatu konsep } \\
\text { dengan benar. }\end{array}$ \\
\hline & 1 & $\begin{array}{l}\text { Mengidentifikasi yang termasuk contoh } \\
\text { atau bukan contoh dari suatu konsep } \\
\text { namun belum benar. }\end{array}$ \\
\hline & 0 & $\begin{array}{l}\text { Salah mengidentifikasi contoh atau } \\
\text { bukan contoh dari suatu konsep. }\end{array}$ \\
\hline $\begin{array}{l}\text { 3. Menggunakan } \\
\text { konsep dengan } \\
\text { benar } \quad \text { dalam }\end{array}$ & 4 & $\begin{array}{l}\text { Mengaplikasikan konsep dalam } \\
\text { berbagai situasi, perhitungan, dan } \\
\text { jawaban akhir benar. }\end{array}$ \\
\hline berbagai situasi & 3 & $\begin{array}{l}\text { Benar mengaplikasikan konsep dalam } \\
\text { berbagai situasi, sebbgaian besar } \\
\text { perhitungan dan jawaban akhir salah. }\end{array}$ \\
\hline & 2 & $\begin{array}{l}\text { Benar mengaplikasikan konsep dalam } \\
\text { berbagai situaasi, namun perhitungan } \\
\text { dan jawaban akhir salah. }\end{array}$ \\
\hline & 1 & $\begin{array}{l}\text { Tidak benar mengaplikasikan konsep } \\
\text { dalam berbagai situasi. }\end{array}$ \\
\hline & 0 & $\begin{array}{l}\text { Tidak membuat jawaban atau hanya } \\
\text { mengulang informasi yang diketahui dari } \\
\text { soal. }\end{array}$ \\
\hline
\end{tabular}

(Dimodifikasi dari NCTM, 2000)

Data pada penelitian ini adalah skor pemahaman konsep matematika siswa yang dikumpulkan melalui tes berbentuk uraian. Dalam penelitian ini, agar instrumen memenuhi syarat yaitu instrumen yang baik, maka dalam penyusunan instrumen (tes), peneliti meminta masukan dari para ahli (expert judgement), yaitu dosen di Jurusan Pendidikan Matematika dan guru matematika SMA Negeri 1 Bangli. Hal ini dilakukan untuk mengetahui apakah tes yang disusun telah mencerminkan materi yang disampaikan.

Tes pemahaman konsep matematika yang telah disusun kemudian diujicobakan untuk mendapatkan gambaran secara empirik tentang kelayakan tes tersebut digunakan sebagai instrumen penelitian. Hasil uji coba dianalisis lebih lanjut untuk mendapatkan validitas dan reliabilitas tes.

Uji coba tes dilakukan pada populasi di luar kelas kontrol dan kelas eksperimen. Soal ini diujicobakan di kelas XI MIPA 4 SMA Negeri 1 Bangli. Soal yang diujicobakan adalah sebanyak 7 butir soal. Hasil uji coba kemudian dilakukan analisis sehingga menghasilkan 6 butir soal yang valid. Keenam butir soal yang valid tersebut sudah mencakup keseluruhan materi yang diajarkan sehingga keenam soal tersebut digunakan sebagai tes kemampuan pemahaman konsep matematika siswa. Setelah dialukan uji validitas, dilakukan uji reliabilitas terhadap 6 butir soal yang valid tersebut. Dari hasil analisis reliabilitas tes diperoleh nilai $r_{11}=0,7297$. Hasil tersebut menunjukkan bahwa tes pemahaman konsep matematika siswa tersebut reliabel dengan derajat reliabilitas sangat tinggi, sehingga soal-soal tersebut layak untuk digunakan.

Setelah siswa diberikan tes pemahaman konsep matematika berbentuk tes essay selanjutnya dilakukan pengujian hipotesis yang diajukan. Terlebih dahulu, data yang diperoleh dilakukan uji prasyarat yakni uji normalitas menggunakan KolmogorovSmirnov dan uji homogenitas varians menggunakan uji-F. Selanjutnya, uji hipotesis dilakukan dengan menggunakn ujit satu ekor (ekor kanan).

\section{HASIL PENELITIAN}

Data mengenai skor pemahaman konsep matematika siswa kelas sampel dapat dilihat pada tabel berikut: 
Tabel 3. Analisis terhadap data Pemahaman Konsep Matematika Siswa

\begin{tabular}{cccc}
\hline No & Variabel & \multicolumn{2}{c}{ Skor Pemahaman Konsep Matematika } \\
\cline { 3 - 4 } & & Kelompok Eksperimen & Kelompok Kontrol \\
\hline $\mathbf{1}$ & $\mathrm{N}$ & 30 & 31 \\
\hline $\mathbf{2}$ & Mean & 27,63 & 25,87 \\
\hline $\mathbf{3}$ & SD & 4,33 & 3,14 \\
\hline
\end{tabular}

\begin{abstract}
Dari tabel 3 dapat dilihat bahwa rata-rata skor kemampuan pemahaman konsep matematika siswa terhadap dua kelas yakni kelas eksperimen dan kelas kontrol menunjukkan bahwa pemahaman konsep amtematika siswa kelas ekseperimen lebih
\end{abstract}

tinggi dibandingkan dengan pemahaman konsep matematika kelas kontrol.

Rangkuman hasil uji normalitas data pada kelompok eksperimen dan kelompok kontrol dapat dilihat pada tabel 4.

Tabel 4. Rangkuman Uji Kolmogorov-Smirnov

\begin{tabular}{cccc}
\hline Kelas & $D_{\text {hitung }}$ & $D_{\text {tabel }}$ & Keterangan \\
\hline Eksperimen & 0,078 & 0,248 & Berdistribusi normal \\
\hline Kontrol & 0,1641 & 0,244 & Berdistribusi normal \\
\hline
\end{tabular}

Dari tabel 4 di atas dapat dilihat bahwa $D_{\text {hitung }}$ kedua kelompok lebih kecil dari $D_{\text {tabel }}$ pada kelas yang bersangkutan. Dengan demikian $\mathrm{H}_{0}$ diterima dan hal tersebut menunjukkan bahwa masing-masing kelas memiliki skor tes pemahaman konsep yang berdistribusi normal.

Homogenitas varians data pemahaman konsep matematika siswa dianalisis dengan uji$F$ dengan kriteria yaitu kedua kelompok memiliki varians homogen jika $F_{\text {hitung }}<F_{\text {tabel. }}$.

Hasil uji homogenitas varians data pemahaman
Diperoleh $F_{\text {hitung }}=1,90$. Berdasarkan tabel-F untuk taraf signifikansi $5 \%$, dk pembilang $=29$ dan $\mathrm{dk}$ penyebut $=30$, diperoleh $\mathrm{F}_{\text {tabel }}=.2,07$. Hal ini berarti $\mathrm{H}_{0}$ diterima yang berarti skor tes pemahaman konsep matematika siswa di kelas eksperimen dan kelas kontrol memiliki varians yang sama.

Selanjutnya dilakukan uji hipotesis dengan uji-t satu ekor (ekor kanan). Adapun rangkuman hasil uji-t dapat dilihat pada tabel berikut:

Tabel 5. Rangkuman Hasil Uji-t

\begin{tabular}{|c|c|c|c|c|c|c|}
\hline Kelompok & $\mathrm{N}$ & Dk & $\bar{X}$ & SD & $t_{\text {hitung }}$ & $t_{\text {tabel }}$ \\
\hline Eksperimen & 30 & 59 & 27,63 & 4,33 & 1,87 & 1,671 \\
\hline Kontrol & 31 & 59 & $\begin{array}{l}25 \\
871\end{array}$ & 3,14 & & \\
\hline
\end{tabular}

Dari Tabel 5. Menunjukkan $t_{\text {hitung }}=1,87$ dan $t_{\text {tabel }}=1,671$. Kriteria pengujian adalah tolak $\mathrm{H}_{0}$ jika $t_{\text {hitung }} \geq t_{\text {tabel. }}$. Karena dari hasil perhitungan menunjukkan bahwa $t_{\text {hitung }}>t_{\text {tabel }}$ maka $\mathrm{H}_{0}$ diterima. Artinya, pemahaman konsep matematika siswa yang mengikuti pembelajaran dengan model pembelajaran penemuan terbimbing dibandingkan lebih baik dengan siswa yang dibelajarkan dengan pembelajaran konvensional. 


\section{PEMBAHASAN}

Hasil analisis terhadap skor pemahaman konsep matematika siswa terhadap kelas eksperimen dan kelas kontrol menunjukkan bahwa rata-rata skor pemahaman konsep matematika siswa pada kelas eksperimen lebih tinggi daripada rata-rata skor pemahaman konsep matematika siswa kelas kontrol. Hal ini dikarenakan model penemuan terbimbing mengarahkan siswa pada proses penemuan konsep sehingga siswa akan lebih mudah dalam memahami setiap konsep yang ingin ditanamkan guru.

Hasil penelitian ini sejalan dengan penelitian-penelitian sebelumnya yang meneliti tentang penerapan model pembelajaran penemuan terbimbing. Dalam penelitian yang dilakukan oleh Agung Fernando (2016) menunjukkan bahwa model pembelajaran penemuan terbimbing berpengaruh signifikan terhadap kemampuan pemecahan masalah matematika siswa. Hasil penelitian ini hanya terbatas untuk melihat ada atau tidaknya pengaruh model pembelajaran penemuan terbimbing terhadap kemampuan pemecahan masalah matematika siswa.

Penelitian lainnya dilakukan oleh Fica Diah Putri (2017) yang menunjukkan bahwa penemuan terbimbing berpengaruh signifikan terhadap kemampuan representasi matematis siswa. Hasil penelitian ini juga terbatas untuk melihat ada atau tidaknya pengaruh model pembelajaran penemuan terbimbing terhadap kemampuan representasi matematika siswa.

Salah satu penyebab adanya perbedaan rata-rata skor pemahaman konsep matematika siswa pada kelompok eksperimen dan kelompok kontrol adalah perbedaan perlakuan antara kelompok eksperimen dan kelompok kontrol. Perlakuan yang dimaksud adalah adanya perbedaan kegiatan pembelajaran yang berlangsung di kelas. Perbedaan tersebut dapat dilihat dari langkah pembelajaran yang dilaksanakan. Pada kelompok eksperimen langkah pembelajaran penemuan terbimbing memiliki kontribusi yang besar dalam meningkatkan pemahaman konsep matematika siswa.

Pada fase stimulation, guru mulai mengarahkan peserta didik untuk membaca buku maupun aktivitas lainnya sebagai persiapan untuk memecahkan permasalahan selama proses penemuan. Antusias siswa terlihat jelas saat guru berusaha mengingatkan mereka pada materi sebelumnya. Beberapa siswa bahkan berani mengacungkan tangan mereka untuk menjawab pertanyaan-pertanyaan yang dilontarkan guru. Melihat antusias siswa tentunya ini secara tidak langsung mengarahkan mereka untuk terus menggali pengetahuan mereka sebelumnya yang berkaitan dengan materi yang diberikan. Situasi ini memperlihatkan usaha siswa untuk menyatakan ulang konsep yang sudah mereka pahami dengan kata-kata sendiri.

Pada fase problem statement, guru mengarahkan siswa untuk menemukan suatu pertanyaan yang mana pertanyaan tersebut mengarahkan peserta didik pada LKS Penemuan Terbimbing. Dalam penelitian ini, sangat terlihat antusias peserta didik saat guru meminta menemukan pertanyaan-pertanyaan yang berkaitan dengan materi yang disampaikan. Satu persatu siswa mencoba mengemukakan pendapatnya. Meskipun ada beberapa pertanyaan yang tidak diharapkan guru, namun semangat yang diperlihatkan siswa membuat guru dapat mengarahkan peserta didik memahami LKS Penemuan Terbimbing. Pada saat guru mengarahkan siswa untuk menentukan hipotesis, sangat terlihat dengan jelas mereka mencoba mengingat kembali dan kemudian mencoba mengungkapkan konsep yang sudah mereka pahami dengan kata-kata sendiri.

Fase data collection, guru membentuk siswa menjadi beberapa kelompok yang dimana masing-masing kelompok terdiri dari 4-5 orang. Selanjutnya, guru memberikan siswa LKS Penemuan Terbimbing untuk didiskusikan di masing-masing kelompok. Pada tahapan ini guru mencoba untuk mengarahkan siswa untuk mencari informasi sebanyak-banyaknya yang berkaitan dengan masalah dalam LKS. Siswa memanfaatkan sumber-sumber terkait lainnya (buku Modul Pembelajaran, buku Paket, dII) untuk membantu mereka menyelesaikan permasalahan di LKS.

Kelompok yang dibentuk secara heterogen membuat guru lebih mudah untuk mengarahkan setiap kelompok. Selain itu, 
dengan belajar secara kelompok, membuat diskusi serta interaksi antara siswa dengan siswa dapat terlaksana dengan baik. Selama proses pengumpulan informasi, antusias dan semangat siswa secara tidak langsung membuat mereka mampu menyatakan ulang konsep dengan kata-kata sendiri serta mampu memberikan contoh dan bukan contoh dai konsep. Dengan kemampuan tersebut tentunya data yang mereka kumpulkan memang benar-benar mendukung fase berikutnya yakni proses pengolahan data.

Fase data processing, siswa mengolah data atau informasi-informasi tersebut untuk membuktikan hipotesis. Pada tahapan ini, keaktifan masing-masing siswa sangat terlihat jelas. Ketika siswa menemukan suatu kesulitan selama proses pemecahan masalah, mereka aktif untuk berdiskusi dengan kelompok dan sesekali menanyakannya kepada guru. Melakukan pengolahan data dengan menjawab pertanyaan-pertanyaan yang diberikan di LKS secara tidak langsung membuat siswa harus mampu menggunakan konsep dengan benar dalam berbagai strategi.

Fase verification, pada tahap ini siswa melakukan pemeriksaan secara cermat untuk menunjukkan benar/tidaknya hipotesis yang mereka rumuskan. Pada tahap ini,guru meminta perwakilan kelompok untuk menyampaikan hasil diskusi kelompoknya kemudian siswa yang lainnya mencoba untuk menanggapi. Kemampuan siswa dalam menyampaikan hasil karya atau menyampaikan hasil diskusi mereka di depan kelas menunjukkan bahwa mereka mampu menyatakan ulang konsep dengan kata-kata sendiri serta memberikan contoh dan bukan contoh dari konsep.

Fase terakhir adalah fase generalization, pada fase ini guru mengajak siswa untuk menyimpulkan atau menggeneralisasi konsep sehingga dapat berlaku untuk umum. Pada tahapan ini, guru menunjuk salah seorang siswa untuk mengemukakan pendapatnya terkait dengan kesimpulan terhadap hasil diskusi kelompok. Banyak siswa yang sebenarnya ingin berkontribusi, namun karena keterbatasan waktu guru hanya menunjuk salah seorang siswa saja. Dari beberapa pertemuan yang dilaksanakan hampir seluruh siswa yang ditunjuk mampu menyatakan ulang serta memberikan contoh dan bukan contoh dari konsep. Bahkan ketika guru memberikan sebuah pertanyaan yang berkaitan dengan pengaplikasian konsep, siswa-siswa yang ditunjuk tersebut mampu menggunakan konsep yang sudah mereka dapatkan dengan sangat baik.

Dari penjelasan-penjelasan di atas, hal yang berbeda terjadi pada kelas kontrol. Pada kegiatan pendahuluan, guru memberikan siswa arahan untuk termotivasi dalam belajar. Pada kegiatan pendahuluan ini sama halnya dengan fase stimulation pada kelas eksperimen. Antusias juga terlihat dengan jelas ketika guru mencoba mengingatkan kembali siswa terkait dengan materi sebelumnya.

Tahapan pembelajaran berikutnya, yakni orientasi peserta didik pada masalah. Pada fase ini siswa diberikan penjelasan serta contoh soal dan penyelesaian yang berkaitan dengan materi yang diajarkan pada pertemuan tersebut. Pada kegiatan menyimak ini siswa cenderung tidak menghiraukan penjelasan guru. Hanya beberapa siswa saja yang mau mendengarkan penjelasan guru. Kemudian pada saat guru memberikan contoh soal dan penyelesaiannya hampir seluruh siswa menyimak dengan sangat baik. Situasi ini, di satu sisi mampu membuat siswa menyelesaikan soal sejenis dengan baik namun di sisi lain konsep yang ingin ditanamkan guru tidak tertanam dengan baik.

Berikutnya tahapan pembelajaran yang dilakukan guru adalah mengorganisasikan peserta didik. Pada tahapan ini, guru akan membentuk siswa menjadi beberapa kelompok. Guru juga mencoba menjelaskan kepada setiap kelompok terkait prosedur pengerjaan LKS. Tahapan ini hampir sama dengan fase data collection. Namun yang membedakan adalah proses pengumpulan data. Jika pada kelompok eksperimen siswa akan mengumpulkan data, sedangkan pada kelompok kontrol siswa tidak melakukan pengumpulan data kembali. Hal ini dikarenakan soal yang diberikan pada LKS berupa latihan-latihan soal yang berkaitan dengan contoh yang sudah diberikan guru.

Tahapan yang selanjutnya adalah mengembangkan dan menyajikan hasil 
karya. Pada tahapan ini hampir sama dengan fase verification pada kelompok eksperimen. Persamaan tersebut yakni siswa menyampaikan hasil diskusi kelompoknya di depan kelas kemudian kelompok lain akan memberikan tanggapan. Perbedaannya dengan fase verification yakni pada tahap ini siswa tidak mendiskusikan konsep baru namun lebih kepada diskusi mengenai soal-soal dan penyelesaian terkait materi yang disampaikan pada pertemuan tersebut.

Sebagai penutup kegiatan, guru mengadakan kegiatan pembelajaran yakni dengan menganalisis dan mengevaluasi proses pemecahan masalah. Pada tahapan ini sebelum siswa menyimpulkan secara umum, siswa diminta untuk mengerjakan soal yang ada di uji kompetensi pada buku paket. Setelah semua siswa dirasa mampu mengerjakan soal yang berkaitan dengan materi yang diberikan pada pertemuan tersebut, berikutnya salah seorang siswa diberikan kesempatan untuk menyimpulkan secara umum pembelajaran pada pertemuan tersebut.

Pembelajaran yang diberikan pada kelas eksperimen dan kelas kontrol memiliki kekurangan dan keunggulan masingmasing. Pada kelas eksperimen karena model ini pertama kali diterapkan oleh guru, kekurangan yang dimaksud lebih mengarah pada kendala-kendala yang dirasakan selama proses pembelajaran berlangsung. Sedangkan pada kelompok kontrol, model yang diterapkan sudah sering dilaksanakan oleh guru sehingga kendala tidak dirasakan namun pembelajaran di kelompok kontrol masih menyimpan beberapa kekurangan.

Kendala-kendala yang dimaksudkan pada pembelajaran yang berlangsung di kelompok eksperimen adalah sebagai berikut:

1. Kurang optimalnya pembagian kerja pada masing-masing kelompok. Dari hasil pengamatan peneliti, masih banyak anggota kelompok yang tidak mau bekerja dengan temannya. Mereka cenderung mengandalkan temannya yang dirasa memiliki kemampuan lebih.

2. Siswa belum terbiasa dengan model pembelajaran penemuan terbimbing. Saat pertama kali model ini diterapkan siswa merasa kebingungan. Khususnya pada saat siswa mengerjakan LKS yang diberikan. Siswa kebingungan sekaligus terkejut dengan permasalahan yang diberikan di LKS.

Meskipun terdapat beberpaa kendala seperti yang dipaparkan di atas, semua kendala tersebut dapat di atasi dengan melakukan upaya yang lebih maksimal lagi untuk membuat siswa paham dengan penerapan model pembelajran penemuan terbimbing ini.

Keunnggulan dari model pembelajaran penemuan terbimbing sudah tentunya dapat dilihat dari pemaparan proses pembelajaran yang dilangsung. Keunggulan tersebut yakni, model pembelajaran penemuan terbimbing memiliki kontribusi yang begitu besar dalam menanamkan pemahaman konsep matematika siswa. Secara umum, dapat dinyatakan bahwa model pembelajaran penemuan terbimbing mampu berjalan baik sesuai dengan harapan dan rencana. Hasil analisis juga menunjukkan hasil yang diharapkan.

Adanya proses penemuan konsep dalam penerapan model pembelajaran terbimbing mampu melatih siswa untuk dapat menyatakan ulang konsep dengan kata-kata sendiri. Kemudian, dari konsep yang berhasil mereka temukan akan membantu mereka untuk dapat memberikan contoh dan bukan contoh dari konsep yang sudah mereka temukan. Hal lainnya yakni siswa akan dengan mudah menggunakan konsep yang mereka gunakan sebab mereka menemukan sendiri konsep tersebut. Jadi, dengan menerapkan model pembelajaran penemuan terbimbing akan membantu siswa memahami konsep matematika.

Kekurangan penerapan pembelajaran konvensional yang berlangsung di kelas kontrol, yakni rendahnya kontribusi penerapan model pembelajaran konvensional dalam menanamkan pemahaman konsep matematika. Meskipun demikian karena model ini sudah sangat dekat sekali dengan siswa, dalam menerapkannya tidak ada kendala yang dirasa berarti. Selain itu, hampir seluruh siswa tidak begitu bingung dan kesulitan saat diberikan pembelajaran dengan penerapan pembelajaran konvensional. 
Dalam hal mengarahkan siswa untuk mampu menjawab soal-soal terkait dengan contoh yang diberikan guru, model ini sangat baik diterapkan. Namun, dalam hal menanamkan pemahaman konsep matematika, model ini cenderung tidak memberikan banyak kontribusi.

Secara umum dapat diberikan kesimpulan bahwa model pembelajaran penemuan terbimbing lebih baik digunakan untuk menanamkan pemahaman konsep matematika siswa dibandingkan dengan pembelajaran konvensional. Terlepas dari kekurangan dan kelebihan yang dimiliki masing-masing model pembelajaran di atas, penerapan model pembelajaran penemuan terbimbing berhasil menanamkan pemahaman konsep matematika siswa. Keberhasilan tersebut telah ditunjukkan berdasarkan uji hipotesis yang dilakukan.

\section{DAFTAR PUSTAKA}

Arends, Richard L. 2007. Learning Ti Teach. Yogyakarta: Pustaka Belajar.

Dantes, Nyoman. 2012. Metode Penelitian. Yogyakarta: Andi

Fernando, Agung. 2016. Pengaruh Penemuan terbimbing Learning Terhadap Minat dan Kemampuan Pemmecahan Masalah Matematika Siswa Kelas IV SD Negeri Debong Kidul Kota Tegal.Tugas Akhir (tidak diterbitkan). Jurusan Pendidikan Matematika, Universitas Negeri Semarang.

Mullis, Ina V.S. dkk. 2015. "TIMSS 2015 International Result in Mathematics (Bostton: Lynch Scholl of Education)". Tersedia pada http://timss2015.org/wpcontent/uploads/filebase/full\%20pdfs/T! $\%$ -

International_Result_in_Mathematics Grade4.pdf (diakses pada Jumat, 27 April 2018).

NCTM. 2000. Mathematics Assesment A Partical handbook for Grades 6-8. United State of America: NCTM
Peraturan Menteri Pendidikan Nasional No. 22 Tahun 2006 tentang Standar Isi untuk Satuan Pendidikan Dasar dan Menengah. 2006. Jakarta: Depdiknas.

Putri, Ficha Diah. 2017. Pengaruh Model Guided Discovery Learning terhadap Kemampuan Representasi Matematis dan Self Cionidence Siswa. Tugas Akhir (tidak diterbitkan). Jurusan Pendidikan Matematika, Universitas Lampung.

Rosmini, Noneng. 2015. Pengaruh Model Pembelajaran Penemuan Terbimbing dalam Meningkatkan Kemampuan Penalaran dan Sikap Matematis Siswa. Tesis (tidak diterbitkan). Jurusan Pendidikan Matematika Universitas Pendidikan Indonesia.

Slameto. 2010. Belajar dan Faktor-faktor yang Mempengaruhinya. Jakarta: PT. Rineka Cipta

Sugiyono. 2012. Metode Penelitian Kuantitatif Kualitatif dan $R$ \& $D$. Bandung: Alfabeta. 